Chirurgia (2017) 112: 367-377

No. 4, July - August

Copyright $\odot$ Celsius

http://dx.doi.org/10.21614/chirurgia.112.4.367

\title{
Indications of the Magnetic Resonance Method in Breast Pathology
}

\author{
Adina Chirita \\ Regina Maria Medical Network, Bucharest, Romania
}

Corresponding author:

Adina Chirita, MD, PhD

Regina Maria Medical Network,

Bucharest, Romania

E-mail: adina.chirita@reginamaria.ro
Received: 03.04.2017

Accepted: 10.05 .2017

\section{Rezumat}

Indicații ale metodei de rezonanță magnetică în patologia sânului

Este cunoscutã incidența crescutã a cancerului de sân. Rata de supraviețuire la 5 ani pentru femeile cu cancer de sân corect tratate este de 90\% în lume, respectiv de 50 \% în România. Evaluarea diagnosticã corectã a sânilor permite un management terapeutic competent. Diagnosticul primar al cancerului de sân include examenul clinic al sânilor, ecografia de sân şi mamografia. Examenul de rezonanața magneticã (RM) nu este o examinare de prima linie, ci trebuie sa se facã țintit, pentru anumite grupuri selectate de paciente. Examenul RM este indicat în: screeningul cancerului de sân la femeile cu risc crescut pentru cancerul de sân şi în cazurile cu diagnostic echivoc sau cu diagnostice contradictorii la ecografie - mamografie şi la pacientele cu sâni denşi mamografic. Examenul RM mamar este cea mai bunã metodã imagisticã în aprecierea dimensiunilor reale ale tumorii inițiale, în detecția leziunilor multifocale şi multicentrice şi a leziunilor reziduale nodulare axilare post-lumpectomie. De asemeni, examenul RM este recomandat pentru stadializarea preoperatorie a cancerului de sân, pentru evaluarea sânului operat şi pentru evaluarea tratamentului chimioterapeutic. Evaluarea preoperatorie RM a sânului scade numãrul intervențiilor chirurgicale necesare pentru a obține margini de rezecție chirurgicale negative, scade ratele de recurențã ale cancerului de sân şi creşte speranța de viațã pe termen lung (supraviețuirea). RM este o metodã potentialã pentru monitorizarea rãspunsurilor precoce în timpul terapiei neoadjuvante, identificând tumorile chimiorezistente şi permite directionarea re-exciziei, precum şi identificarea tumorilor reziduale dupã terminarea curei de terapie neoadjuvantã. Examenul este foarte util în diagnosticarea patologiei mamare la bãrbat şi 
este recomandat anterior interventiilor chirurgicale de augmentare sau reconstrucție a sânului, pentru aprecierea integritãții implantului mamar.

Cuvinte cheie: rezonanața magneticã, sân

\begin{abstract}
The high incidence of breast cancer is a known fact. The 5-year survival rate for women with correctly treated breast cancer is $90 \%$ around the world, and 50\% in Romania, respectively. Correct diagnostic evaluation of the breasts allows for a competent therapeutic management. The primary diagnosis of breast cancer includes clinical examination of the breasts, breast ultrasound and mammography. Magnetic resonance imaging (MRI) examination is not a first line type of investigation, but targeted to selected patient groups. MRI exam is indicated in: screening of breast cancer in women at high risk for breast cancer, in cases with equivocal diagnosis or with contradictory diagnoses at mammography-ultrasound examinations, and in patients with mammographically dense breasts. Mammary MRI exam is the best imaging method in assessing the real dimensions of the initial tumour, in the detection of multifocal and multicentric lesions and of nodular axillary post-lumpectomy lesions. Also, MRI exam is recommended for preoperative breast cancer staging, for assessment of the breast operated on, and for evaluating chemotherapy. Preoperative MRI assessment of the breast reduces the number of surgical interventions required to obtain surgical negative resection margins, decreases breast cancer recurrence rates, and increases long-term life expectancy (survival). MRI is a potential method for monitoring early responses during neoadjuvant therapy, identifying chemoresistant tumours, and allowing guided re-excision, as well as identifying residual tumours after completion of the neoadjuvant therapy course. The exam is very useful in diagnosing mammary pathology in men and is recommended prior to augmentation or reconstructive breast surgery, to appreciate the integrity of the breast implant.
\end{abstract}

Key words: magnetic resonance imaging, breast

\section{Introduction}

Breast cancer in the world accounts for $30 \%$ of all forms of cancer in women and the second cause of mortality in women after lung cancer. A woman out of eight has a potential risk of developing breast cancer. 180000 breast cancers are diagnosed annually, and the 5-year survival rate with no relapse for women with correctly treated breast cancer is $90 \%$.

In Romania, the incidence of breast cancer has 2 age peaks (35-40 years, early menopause). Breast cancer is the first cause of female mortality. 6000 cases are diagnosed annually. One in 10 women is at risk of having breast cancer during their lifetime, and the 5-year survival rate with no relapse for women with correctly treated breast cancer is $50 \%$.

The MR exam is not a first-line examination, being a laborious and expensive imaging exploration in relation to primary imaging diagnostic methods: ultrasound and mammography. MR screening should be targeted in selected patient groups. The MR examinations according to the EUSOMA 2016 working group are presented in the Table 1.

\section{Preoperative Staging}

Staging of breast cancer involves assessing the local extension of the breast lesion, assessing the contralateral breast and the axils. The 
Table 1. New MR indication

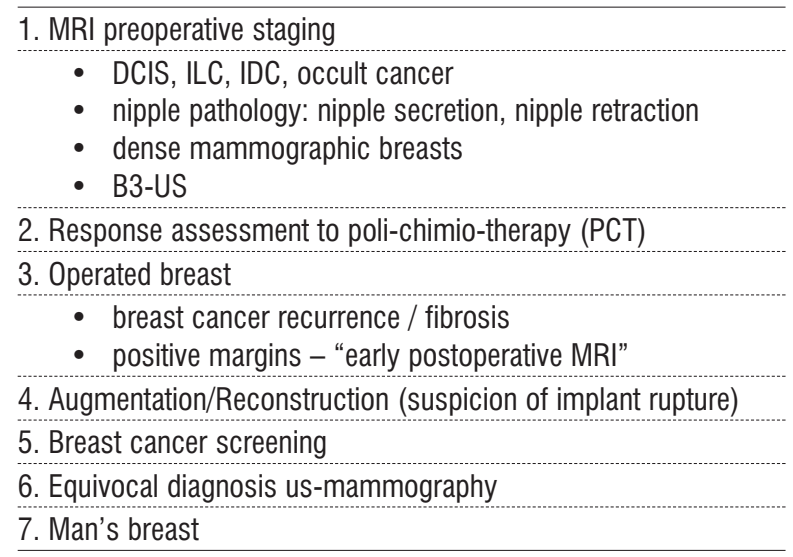

primary diagnosis of breast cancer includes breast examination, breast ultrasound and mammography and has a sensitivity of $99 \%$. The sensitivity of mammography is $60 \%$ and of ultrasound is $83 \%$ (1).

Magnetic Resonance (MR) has proven to be a more accurate method, illustrating with finesse and accuracy the size and vascularization of the tumor, both for circumscribed nodular lesions of "mass" type, but also for infiltrative lesions, imprecisely delimited, also called "non-mass lesions" $(2,3)$. Retrospective studies have shown that mammary MR exam detects other malignant lesions in addition to the primary imaging diagnosis in the ipsilateral breast (in a percentage between $10 \%$ and $27 \%$ $(4,5)$. Ocular, contralateral, synchronous breast cancer is also diagnosed in $\sim 3 \%$ of the patients (6).

$\mathrm{MR}$ is recommended in preoperative staging for the following subgroups of patients (7) (Fig. 1):

- recently diagnosed breast cancer patients,

- patients who have dense breast tissue at mammography,

- for invasive lobular carcinoma (ILC), ductal carcinoma in situ (DCIS),

- in nipple pathology,

- for patients with indication of nonadjuvant chemotherapy.

\section{Recently Diagnosed Breast Cancer Patients}

Ductal carcinoma in-situ (DCIS) may be a unifocal or multifocal lesion, rarely multicenter. $14-75 \%$ of DCIS progresses into invasive ductal carcinoma (IDC). Both invasive lobular carcinoma (ILC) and tumors that associate DCIS are often underestimated in

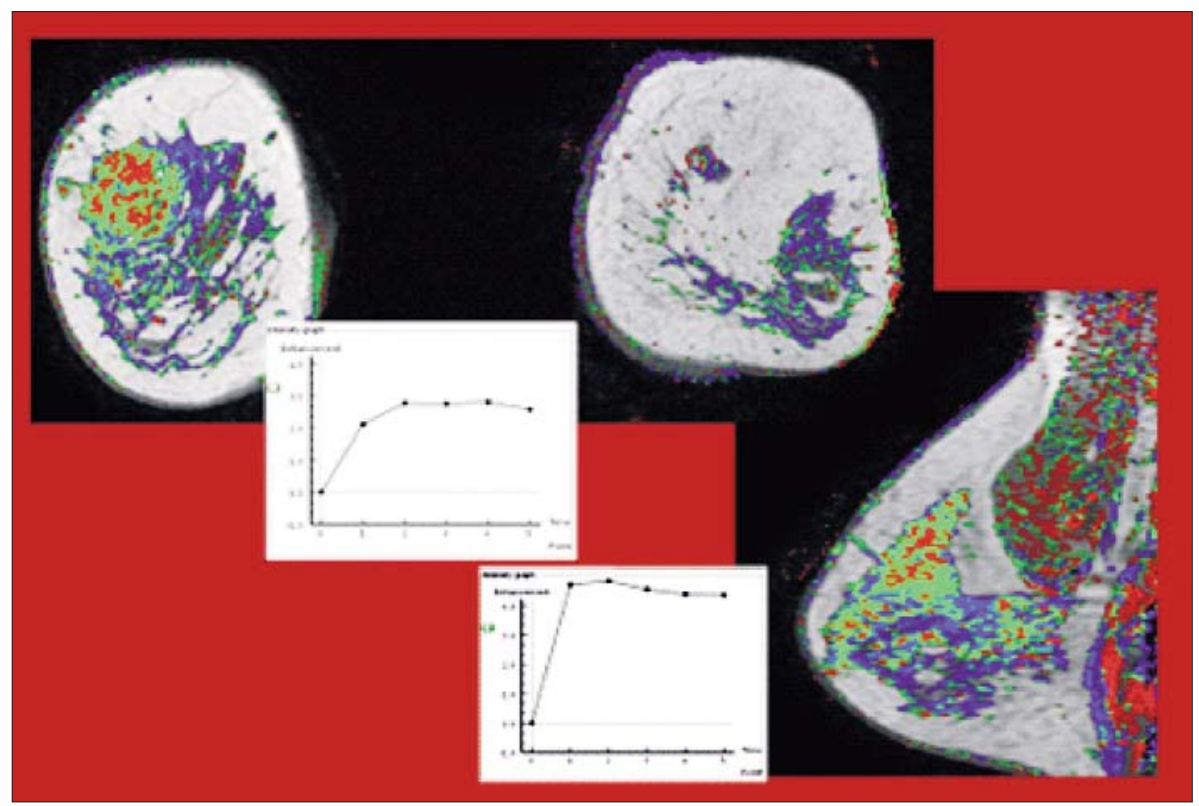

Figure 1. Intratumoral heterogeneity 


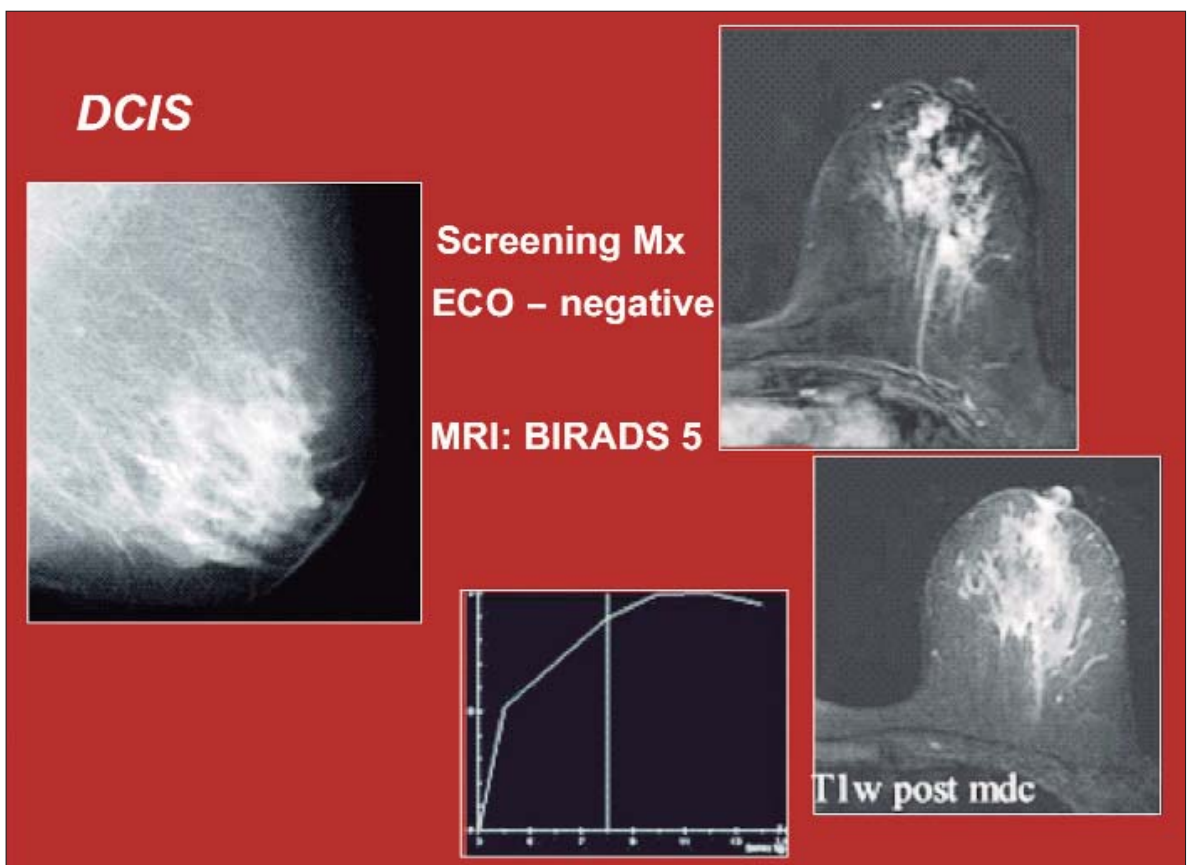

Figure 2. MR indications

mammography (Fig. 2).

$16-47 \%$ of DCIS does not show microcalcifications. It is difficult to obtain negative surgical resection margins in conservative breast therapy for these tumors $(8,9)$. Several recent studies have shown that the MR exam is superior to mammography in DCIS and ILC detection, with $92 \%$ sensitivity to DCIS detection with and without calcifications, compared to mammography that has a sensitivity of $56 \%$ $(10,11)$. These patients may benefit from a much more accurate assessment of the preoperative disease extension using magnetic resonance.

ILC non-mass infiltrative lesions may be dimensionally underestimated in primary imaging assessments of ultrasound or mammography, which explains the increased incidence of cases with positive surgical resection margins in conservative breast treatment. The sensitivity of mammography for ILC detection was reported between $34-81 \%$, being inversely correlated with breast mammography. The sensitivity of MR for ILC is $93-96 \%(1,12)$ (Fig. 3).

Dillon et al. reported that positive surgical resection margins appear in approximately 50\% of patients who were diagnosed with ILC and did not undergo preoperative MRI, compared with $25 \%$ of ILC patients who underwent an MR examination prior to surgical intervention. (3).

\section{Tumors Located in the Posterior Breast}

Tumors located in the posterior breast are difficult to be fully evaluated mammographically. Muscular invasion is difficult to detect by ultrasound. MR exam can be useful in detecting the tumor invasion of the preoperative muscle and anterior thoracic wall. Tumor invasion is identified by pathological contrast enhancement of pectoral muscles, either infiltrative or as focal lesion. Deletion of adipose tissue between the tumor and muscle and extension of vascular structures from the tumor to the muscle without associated pathological contrast enhancement does not indicate tumor invasion (13).

There are studies that reported the identification of primary ocular breast cancer through the MR exam in $62-86 \%$ of patients. Often the primary tumors identified have less than $2 \mathrm{~cm}$ 


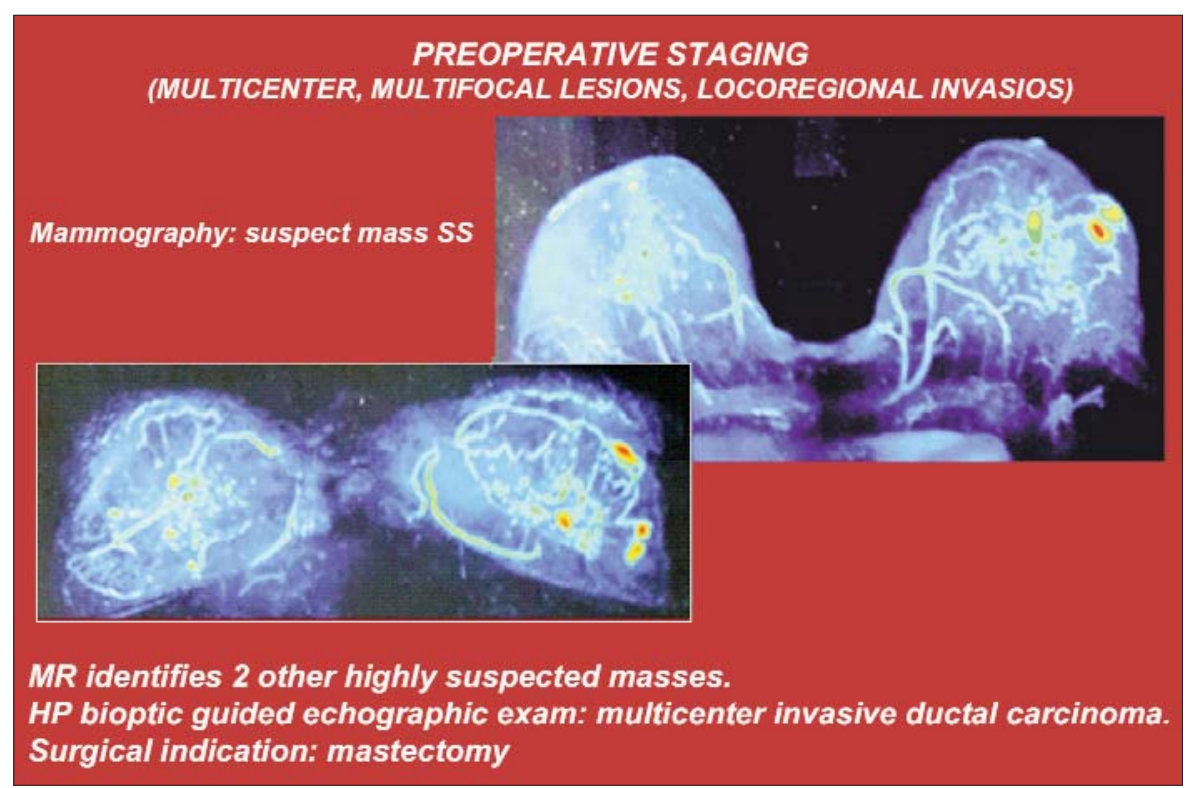

Figure 3. Indications of MR breast exam

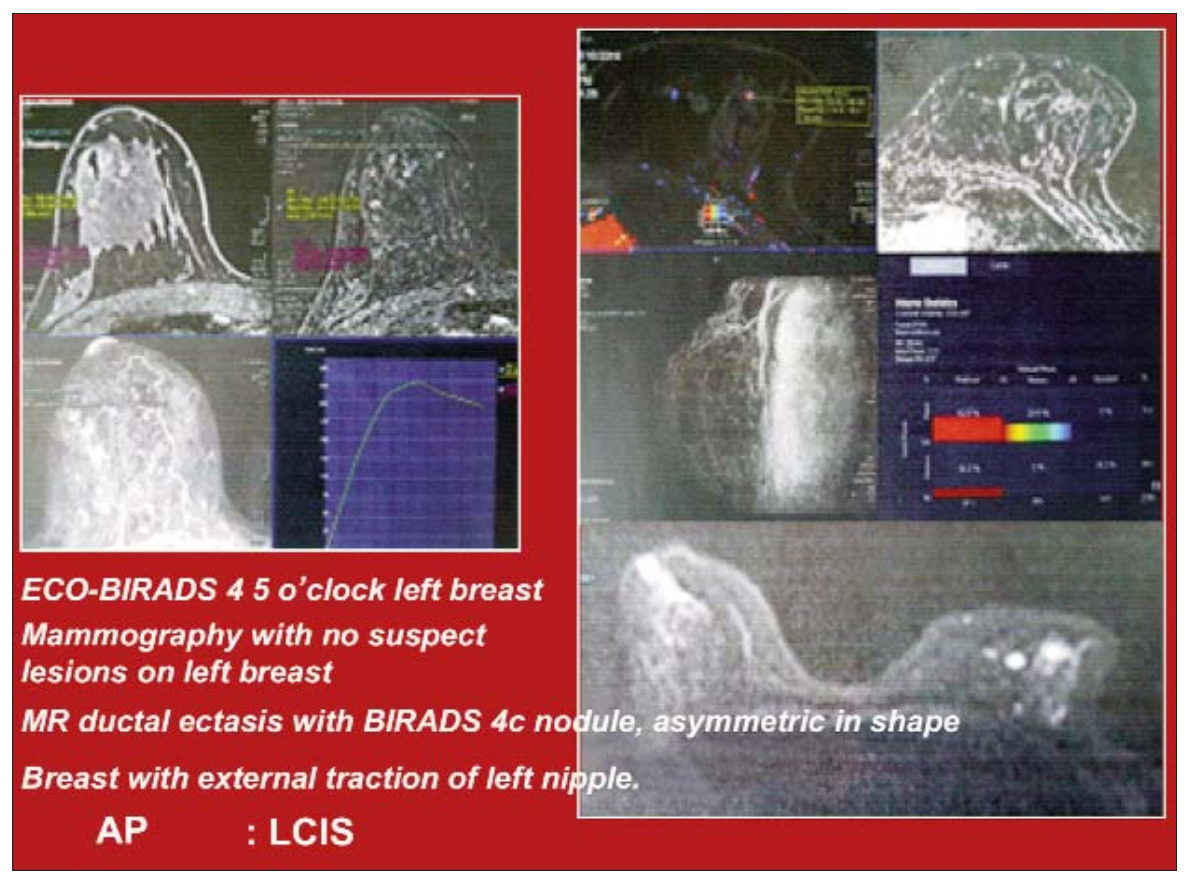

Figure 4. Primary occult cancer

in diameter (14) (Fig. 4).

The occult tumor identified in the collateral breast is present in $6 \%$ of recently diagnosed ILC patients and 3\% among IDC patients (L6).

\section{The Nipple Secretion or Retraction}

The nipple secretion or retraction is a new indication for magnetic resonance breast evaluation. The nipple secretion occurs both for 
physiological and pathological reasons. The secretion of hormonal physiological causes (hypothyroidism, pituitary adenoma with hyperprolactinemia, etc.) or in a medical context is bilateral, from several ducts and looks milky or greenly. Pathological secretion can occur in the presence of a papilloma (48\%), ductal ectasia $(15 \%-20 \%)$ or in carcinoma (1 $45 \%)$, is spontaneous, sanguine, unilateral, located in a single duct.

In the Figs. 5, 6 are presented various cases that associate unilateral nipple secretion, some associating also nipple retraction.

Dense mammography breasts hide malignant lesions and limit the correct assessment of disease outbreaks. The sensitivity of mammography decreases proportionally with increasing breast density, while breast density does not affect the sensitivity of magnetic resonance (1) (Fig. 7).

A new controversial indication of MR examination suggested by EUSOMA in 2012 is the hypervascularized/borderline BIRADS 3 lesions (Fig. 8).

The pre-operative assessment of the MRI breast exam offers important benefits: provides better surgical therapeutic management, decreases the number of surgical interventions required to achieve negative surgical resection margins, lowers recurrence rates of breast cancer, and improves/increases long-term life expectancy (survival).

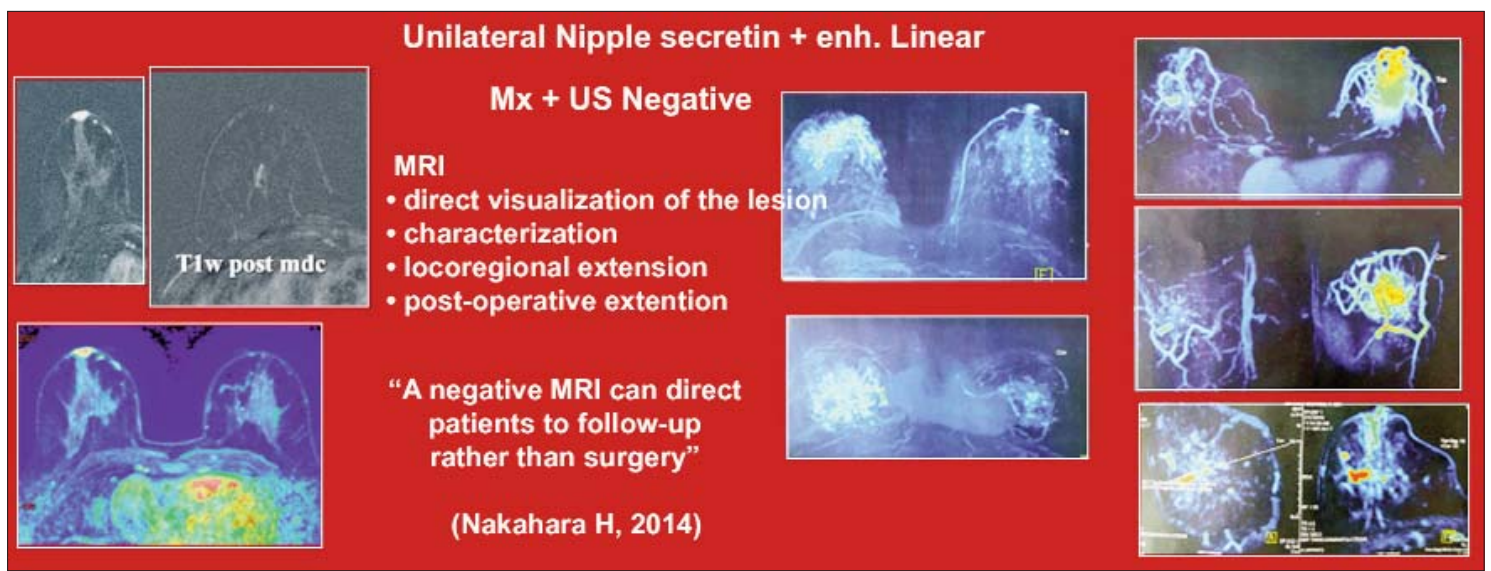

Figure 5.

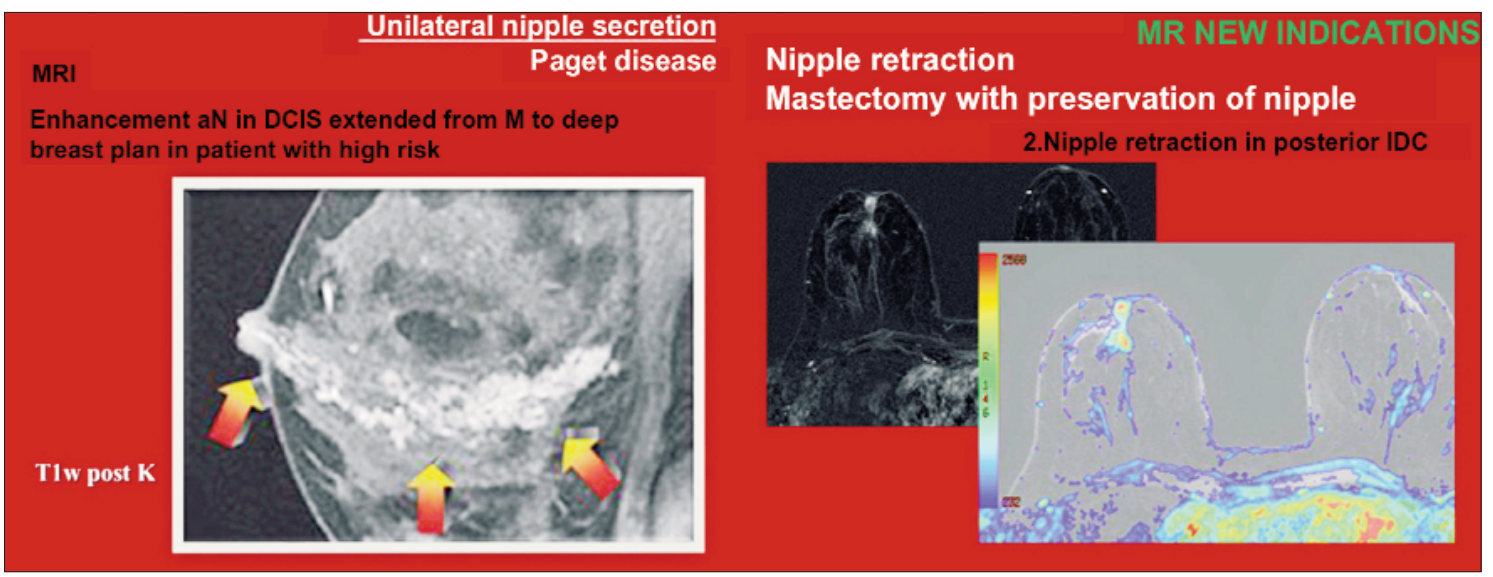

Figure 6. 

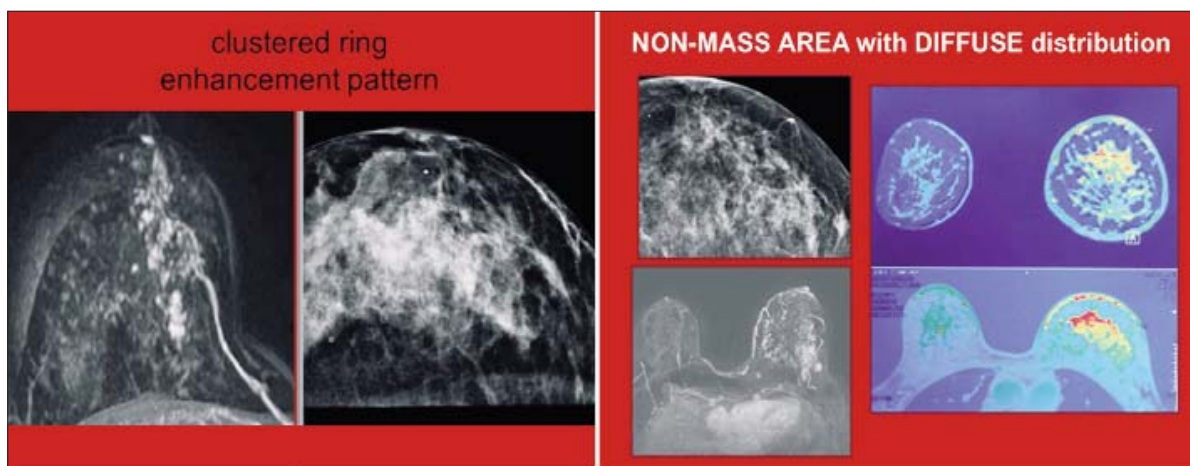

REGIONAL NON-MASS AREA PPV $59 \%$

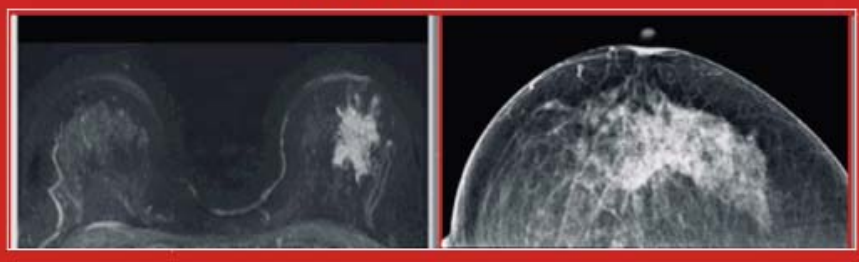

Figure 7.

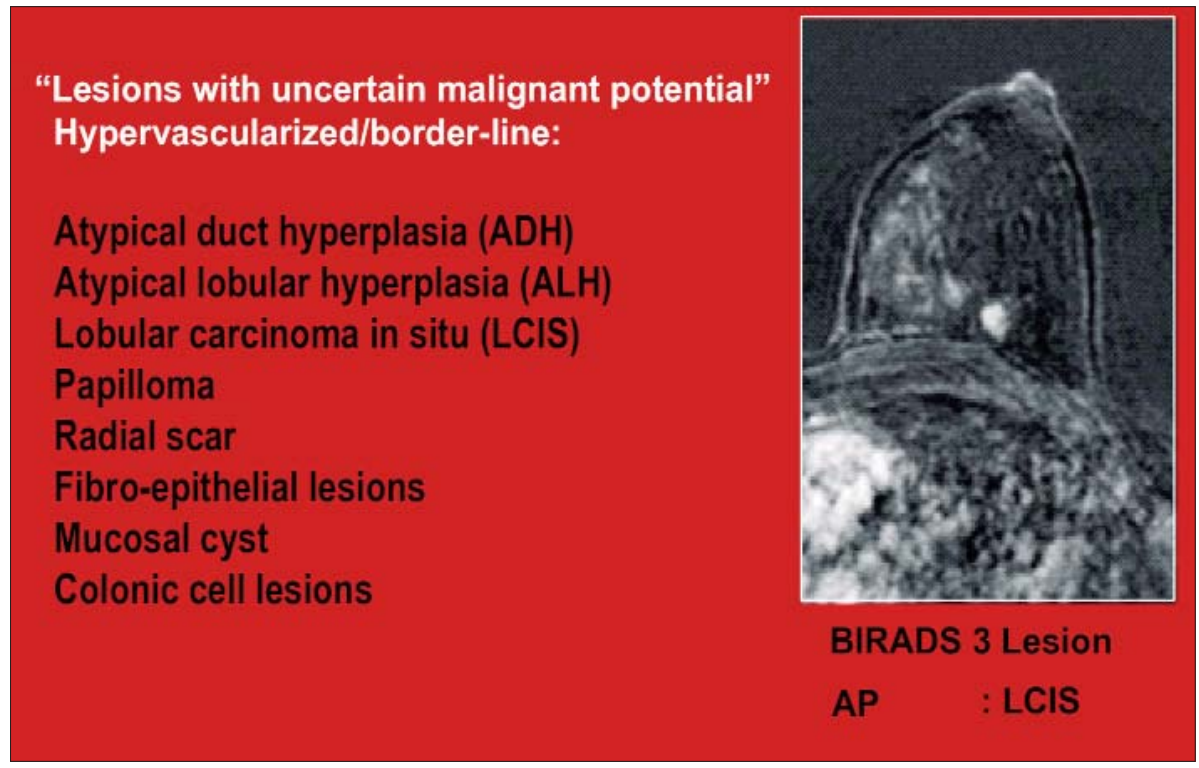

Figure 8.

\section{Evaluation of Chemotherapy}

Patients with axillary metastases and those in advanced stages of local disease can receive poli-chimio-therapy (PCT). In some cases,
PCT treatment is administered to decrease the size of the preoperative tumor to provide breast preservation. Studies in patients who have a complete post-chemotherapy pathological response, defined by the absence of a 
residual lesion in the pathological specimen, have shown that they have better survival/ success results (15).

Breast MR is the best imaging method in assessing the actual size of the initial tumor, as well as identifying residual tumors after the end of the neoadjuvant therapy. The MR examination may overestimate or underestimate the residual lesion, but a more accurate correlation of the MR outcome with the $71-90 \%$ pathological specimens was demonstrated, compared with the clinical examination (with accuracy of 19\%$60 \%)$, ultrasound (35-75\%) and mammography (26-70\%) (16) (Table 2).

\section{MR in Neoadjuvant Therapy}

- MR is the best imaging method to assess tumor changes before and after treatment offering;

- Excellent contrast: tumor/normal tissue;

- Assessment of tumor kinetics: postcontrast;

- Differentiation between necrosis/fibrosis;

- ADC standard measures easy comparison anytime.

MRI is a potential method for monitoring early responses during neoadjuvant therapy by determining diffusion coefficients between lesions prior to PCT treatment, in the middle of the treatment and after PCT treatment, identifying chemosensitive tumors.
Table 2. MR in neoadjuvant therapy

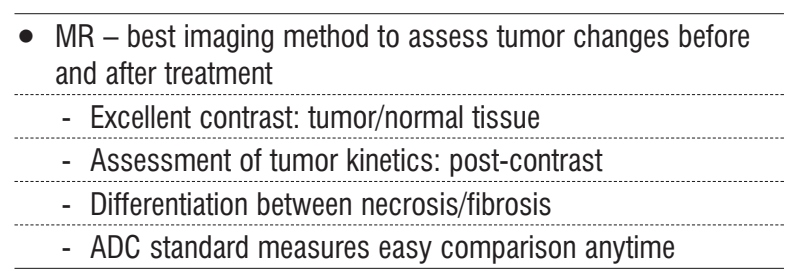

\section{Operated Breast}

Residual microscopic disease at the level of surgical resection margins is known. Patients treated with conservative therapy with positive resection margins are indicative of a new surgical excision. Mastectomy is usually recommended if the resection margins remain positive. Breast MRI in these patients performed early is helpful in identifying the extent of residual disease. The appearance of MR is a peripheral nodular or nodular contrast load, the evidence of this gadophilia being useful in surgical planning for re-excision, allowing prospective identification of patients eventually requiring mastectomy. The goal of MRI is to detect the presence of multifocal and multicenter lesions as well as to detect residual nodular post-lumpectomy axillary lesions to allow re-excision targeting (Fig. 9).

The sensitivity of the MR to the evidence of outstanding lesions in the resection plan is of $92 \%$, the specificity of $69 \%$, the positive

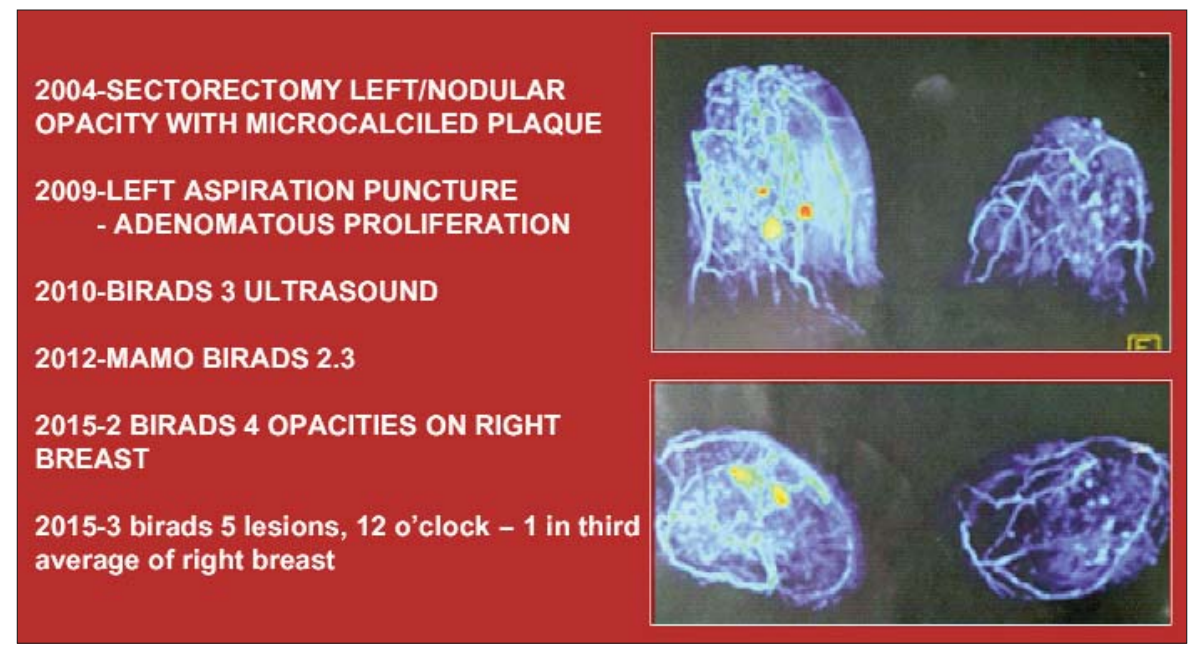

Figure 9. 
predictive value is of $89 \%$. Granulation tissue may increase in the immediate postoperative period. The lowest number of false-positive results was found when MR was performed 35-42 days after the surgical intervention.

\section{Axillary Lymph Node Metastasis with Unknown Primary Tumor}

Patients with axillary metastasis without any evidence of breast cancer at physical examination or mammography represent less that $1 \%$ of all cases of breast carcinoma. The importance of identifying a malignant tumor is two times higher. This gives the patient the option of conservative breast therapy instead of mastectomy, the procedure usually occurs when the primary tumor is not identified. Also, hormonal and chemotherapeutic treatments may be provided when histology of the primary tumor is known. Breast MRI is strongly indicated for these patients.

\section{Augmentation of Reconstruction}

\section{Integrity of the Silicone Breast Implant}

Unlike the saline implant rupture, which is readily observable at the physical examination, the rupture of the silicone implant can be difficult to identify. The MR exam is the imaging method that allows detection of the silicone implant rupture, the method having a sensitivity of $78-100 \%$ and a specificity of 63-91\% (17,18). Silicone is hyperintensive in T2 weighting in IR recovery inversion with long TE echo time. Intracapsular implant rupture occurs when the implant walls degrade, but silicone remains trapped in a body-shaped fibrous capsule. Deterioration of the implant walls is highlighted in the MR by the "linguine sign" and the keyhole sign". Extracapsular rupture occurs when free silicone fragments pass beyond the fibrous capsule into the breast or axilla (Fig. 10).

\section{Breast Cancer Screening}

Mammographic screening is the only imaging modality that has been shown to decrease breast cancer mortality in the general population. Breast MR allows detection of an increased number of small malignant nodular or nonmalignant lesions in women with high risk for breast cancer and is a useful screening tool when used in women with high risk for breast cancer (18). However, due to limited specificity and high cost, the MR exam is not suitable for screening the general population. The ACS recommended the annual screening of the MR mammary exam for high-risk women including:

- Women with BRCA1 and BRCA2 gene

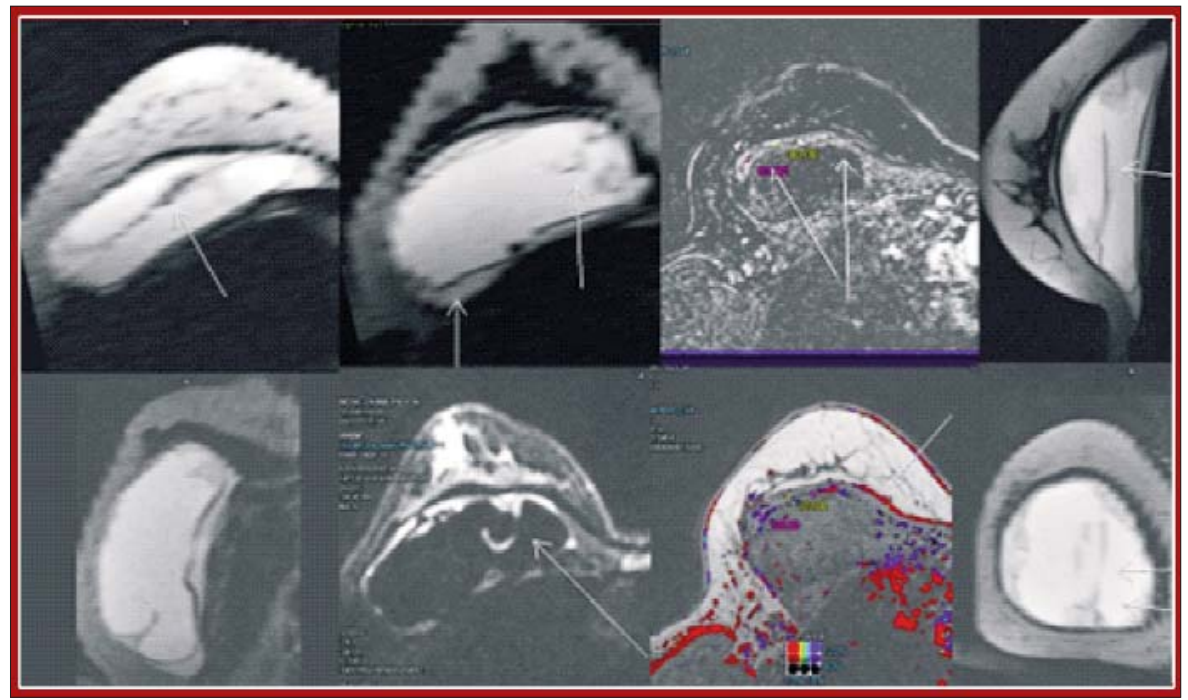

Figure 10. Intracapsular silicone implant rupture 
mutations and their untested first degree relatives;

- Patients with thoracic radiation between the ages of 10 and 30 years;

- People with certain associated syndromes predisposing to breast cancer;

- Patients with a lifetime risk of more than $20-25 \%$ determined by risk models (women with relatives of first grade with breast or ovarian cancer).

There is insufficient evidence for and against MRI screening for intermediate risk women, including:

- Women with $15-20 \%$ risk of breast cancer defined by risk models;

- Patients previously diagnosed with atypia or lobular carcinoma in situ;

- Patients with dense mammographic breasts, or

- Patients with a history of breast cancer.

\section{Equivocal Diagnosis Ultrasound - Mammography}

Using Breast MR as a tool for solving cases with equivocal or controversial ultrasound mammography is controversial. The MR should not be performed to avoid biopsy of a mammographic, ultrasound suspicion or of a palpable lesion (Fig. 11).

Studies with large batches of patients with equivocal mammography diagnostic results revealed a sensitivity of the MR exam of $100 \%$ and a specificity of $92 \%$. The negative predictive value of the MR in determining the diagnosis for suspicious or uncertain lesions in mammography or ultrasound is $85 \%$ and does not rule out the need for a biopsy (19).

\section{Conclusions}

Breast MR is a valuable imaging tool complementary to first-line imaging examinations, i.e. the ultrasound and mammography. Because of the high cost and limited specificity, it is necessary to use the MR breast exam as indicated. Breast MR is the best imaging method in assessing the accurate tumor extension as well as identifying residual tumors after the end of the PCT cure. The MR exam has the role of detecting multifocal and multicenter lesions, non-mass infiltrative lesions, occult lesions, or post-lymphadenectomy residual axillary lesions. The exam is very useful for young women with dense breasts and increased risk factors for breast cancer, in breast implant assessment and diagnosis of mammalian pathology in men.

The pre-operative assessment of the MRI breast exam offers important benefits: provides better surgical therapeutic management, decreases the number of surgical interventions, lowers recurrence rates of breast cancer being useful in surgical planning for re-excision allowing for prospective identification of patients which eventually require a mastectomy. Finally, the MR exam improves lincreases long-term life expectancy (survival).

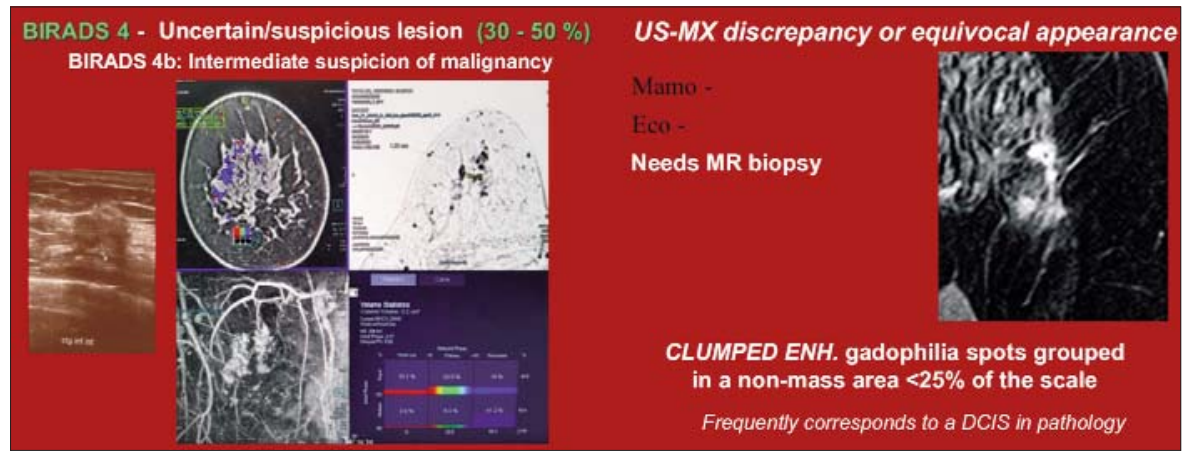

Figure 11. 


\section{References}

1. Berg WA, Gutierrez L, NessAiver MS, Carter WB, Bhargavan M, Lewis RS, et al. Diagnostic accuracy of mammography, clinical examination, US, and MR imaging in preoperative assessment of breast cancer. Radiology. 2004;233(3):830-49. Epub 2004 Oct 14.

2. Rodenko GN, Harms SE, Pruneda JM, Farrell RS Jr, Evans WP, Copit DS, et al. MR imaging in the management before surgery of lobular carcinoma of the breast: correlation with pathology. AJR Am J Roentgenol. 1996;167(6):1415-9.

3. Dillon MF, Hill AD, Fleming FJ, O'Doherty A, Quinn CM, McDermott EW, et al. Identifying patients at risk of compromised margins following breast conservation for lobular carcinoma. Am J Surg. 2006;191(2):201-5.

4. Schelfout K, Van Goethem M, Kersschot E, Colpaert C, Schelfhout $A M$, Leyman $P$, et al. Contrast-enhanced MRI imaging of breast lesions and effect on treatment. Eur J Surg Oncol. 2004;30(5):501-7.

5. Schnall MD, Blume J, Bluemke DA, Deangelis GA, Debruhl N, Harms S, et al. MRI detection of distinct incidental cancer in women with primary breast cancer studied in IBMC 6883. J Surg Oncol. 2005;92(1):32-8.

6. Lehman CD, Gatsonis C, Kuhl CK, Hendrick RE, Pisano ED, Hanna $\mathrm{L}$, et al. MRI evaluation of the contralateral breast in women with recently diagnosed breast cancer. N Engl J Med. 2007;356(13): 1295-303. Epub 2007 Mar 28.

7. American College of Radiology Practice Guidelines for the Performance of Magnetic Resonance Imaging of the Breast. Available at:http:// www.acr.org. Accessed onSeptember 13, 2010.

8. Berg WA. Imaging the local extent of disease. Semin Breast Dis. 2001;4:153-173.

9. Hwang ES, Kinkel K, Esserman LJ, Lu Y, Weidner N, Hylton NM. Magnetic resonance imaging in patients diagnosed with ductal carcinoma-in-situ: value in the diagnosis of residual disease, occult invasion, and multicentricity. Ann Surg Oncol. 2003;10(4):381-8.

10. Kuhl CK, Schrading S, Bieling HB, Wardelmann E, Leutner CC, Koenig $\mathrm{R}$, et al. MRI for diagnosis of pure ductal carcinoma in situ: a prospective observational study. Lancet. 2007; 370(9586):485-92.
11. Mann RM, Balleyguier C, Baltzer PA, Bick U, Colin C, Cornford E, et al. Breast MRI: EUSOBI recommendations for women's information. Eur Radiol. 2015;25(12):3669-78. doi: 10.1007/s00330-015-3807-z. Epub 2015 May 23.

12. Mann RM, Hoogeveen YL, Blickman JG, Boetes C. MRI compared to conventional diagnostic work-up in the detection and evaluation of invasive lobular carcinoma of the breast: a review of existing literature. Breast Cancer Res Treat. 2008;107(1):1-14. Epub 2007 Feb 15.

13. Morris EA, Schwartz LH, Drotman MB, Kim SJ, Tan LK, Liberman $L$, et al. Evaluation of pectoralis major muscle in patients with posterior breast tumors on breast MR images: early experience. Radiology. 2000;214(1):67-72.

14. Orel SG, Weinstein SP, Schnall MD, Reynolds CA, Schuchter LM, Fraker DL, et al. Breast MR imaging in patients with axillary node metastases and unknown primary malignancy. Radiology. 1999; 212(2):543-9.

15. Kaufmann M, von Minckwitz G, Smith R, Valero V, Gianni L, Eiermann W, et al. International expert panel on the use of primary (preoperative) systemic treatment of operable breast cancer: review and recommendations. J Clin Oncol. 2003;21(13):2600-8.

16. Yeh E, Slanetz P, Kopans DB, Rafferty E, Georgian-Smith D, Moy L, et al. Prospective comparison of mammography, sonography, and MRI in patients undergoing neoadjuvant chemotherapy for palpable breast cancer. AJR Am J Roentgenol. 2005;184(3):868-77.

17. Goodman CM, Cohen V, Thornby J, Netscher D. The life span of silicone gel breast implants and a comparison of mammography, ultrasonography, and magnetic resonance imaging in detecting implant rupture: a meta-analysis. Ann Plast Surg. 1998;41(6):57785; discussion 585-6.

18. Di Benedetto G, Cecchini S, Grassetti L, Baldassarre S, Valeri G, Leva $L$, et al. Comparative study of breast implant rupture using mammography, sonography, and magnetic resonance imaging: correlation with surgical findings. Breast J. 2008;14(6):532-7. doi: 10.1111/j.1524-4741.2008.00643.x.

19. Bluemke DA, Gatsonis CA, Chen MH, DeAngelis GA, DeBruhl N, Harms S, et al. Magnetic resonance imaging of the breast prior to biopsy. JAMA. 2004;292(22):2735-42. 